\title{
Determination of the quality changes of whole cuttlefish (Sepia officinalis, L., 1758) stored at $2^{\circ} \mathrm{C}$
}

\section{Bütün olarak $+2^{\circ} \mathrm{C}$ 'de depolanan mürrekkep balığının (Sepia officinalis, $L_{\text {. }}$ 1758) kalite değişimlerinin tespit edilmesi}

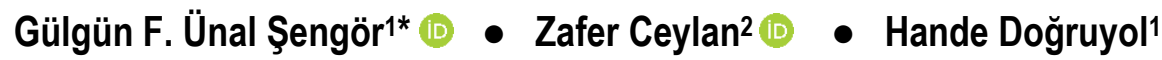 \\ ${ }^{1}$ Istanbul University, Faculty of Aquatic Sciences, Department of Fishing and Seafood Processing Technology, Laleli-Istanbul, Turkey \\ 2 Van Yüzüncü Yıl University, Faculty of Fisheries, Department of Fishing and Seafood Processing Technology, Van, Turkey \\ *Corresponding author: sengor@istanbul.edu.tr \\ Received date: 05.02.2018
}

Accepted date: 06.03 .2018

How to cite this paper:

Ünal Şengör, G.F., Ceylan, Z. \& Doğruyol, H. (2018). Determination of the quality changes of whole cuttlefish (Sepia officinalis, L., 1758) stored at $2^{\circ} \mathrm{C}$. Ege Journal of Fisheries and Aquatic Sciences, 35(2), 115-119. DOI:10.12714/egejfas.2018.35.2.02

\begin{abstract}
The objective of this study was to determine sensorial, microbiological and physicochemical quality of whole cuttlefish (Sepia officinalis) during the stored without ice in refrigerator temperature. Sensory (quality index method [QIM]), physicochemical ( $\mathrm{pH}$, moisture, color measurement, trimethylamine nitrogen [TMA$\mathrm{N}$ ], total volatile bases nitrogen [TVB-N] values and ammonia value $\left[\mathrm{NH}_{3}\right]$ ) and microbiological analysis [total psychrotrophic bacteria and mesophilic aerobic bacteria] were determined during storage period. The results indicate that the shelf life of cuttlefish stored was found as 6 days at $2^{\circ} \mathrm{C}$ "acceptable quality".Sensory and physicochemical quality loss and certain deterioration of cuttlefish was determined that unacceptable 9 days at $2^{\circ} \mathrm{C}$.
\end{abstract}

Keywords: Cuttlefish, physico-chemical quality indices, microbiological quality, color, sensory

Öz: Bu çalışmanın amacı buzsuz olarak buzdolabı koşullarında depolanan mürekkep balığııın duyusal, mikrobiyal ve fiziko-kimyasal kalitesinin ortaya konulmasıdır. Duyusal (kalite indeks metodu [QIM], fiziko-kimyasal (pH, nem, renk ölçümü, trimetilamin azot [TMA-N], toplamuçucu bazik azot [TVB-N], amonyak değerleri) ile mikrobiyal analiz [toplam psikrofilik bakteri ve mesofilik aerobik bakteri] sonuçları depolama periyodu boyunca değerlendirilmiştir.

+2 derecede depolanan mürekkep baliğının raf ömrü 6 gün süresince kabul edilir kalitede olduğu tespit edilirken, 9. günde duyusal, fiziko-kimyasal bozulmalar ve kayıplar açısından kesin bozuk olduğu tanımlanmışıı.

Anahtar kelimeler: Mürekkep balığı, fiziko-kimyasal kalite göstergeleri, mikrobial kalite, renk, duyusal

\section{INTRODUCTION}

Cephalopods are main group of invertebrates and one of the great consumer demand mainly as chilled and frozen in the coastline of Turkey. Known as common cuttlefish, Sepia officinalis, belongs to the Sepiidae family are commonly captured among of cephalopods from Aegean, Mediterranean and Marmara Sea. According to Fishery Statistics, 745 tonnes of cuttlefish were caught from Aegean, Mediterranean and Marmara Sea (TUIK 2016). Cuttlefish is a highly nutritious invertebra due to being rich in omega-3 fatty acids and a perfect protein source (Unal, 1991; Ozogul et al., 2008).

The consumer demand for fresh cuttlefish has remarkably increased due to its aroma and flavour. Lately, the delicious meal such as fried and stuffed cuttlefish are highly consumed by Turkish people living in the coastline of Turkey. Therefore the study of freshness quality of cuttlefish is one of interest to retailers and consumers. Cuttlefish, being highly perishable, deteriorate rapidly if not stored at cold temperatures. For hence, it must be stored at cold storage temperature to protect its freshness until transferred to domestic market immediately. If fresh cuttlefish after capture is not keep in cold chain it undergo the changes in texture, flavour and discoloration rapidly. The state of freshness of cuttlefish is an important factor for its commercial value. It is generally exposed to on the air in fishmongers during it sale. Like other seafood, cuttlefish is rapid deterioration due to microbial activity and/or spoilage specific chemical reactions. In order to prevent microbial deterioration, it should rapidly be cooled down at a low temperature $\left(-2^{\circ} \mathrm{C}\right)$ and be kept at cold storage temperature (between $0^{\circ} \mathrm{C}$ to $4^{\circ} \mathrm{C}$ ). Sometimes, fishmongers do not pay attention while selling their seafood under the sunlight all day long. As a result of their bad habits the change in the external appearance of cuttlefish, specially related to a decrease in the skin into a pale dark 
brownish color and loss of brightness indicating a loss in initial quality of cuttlefish. There are only few studies on cuttlefish quality assessment, most of them are related to determining the chemical, microbiological and sensory changes of the whole cuttlefish during iced storage (Ganesan et al., 2005; Vaz-Pires et al., 2008; Sykes et al., 2009; Tantasuttikul et al., 2011; Jeyasekaran et al., 2012).Quality assessment of cuttlefish is determined using sensory, chemical and microbiological analysis. Sensory analysis is commonly considered as the most important method for freshness evaluation in the fish research (Martinsdóttir et al., 1987). Quality index method is commonly used to evaluate seafood freshness quality. In addition to, physical, chemical and microbiological analyses are also used to assess the freshness quality of seafood.There is little study assessing quality deterioration of cuttlefish in the storage of at different temperatures without ice treatment (Ganesan et al., 2005).

The objectives of this study were to investigate the shelf life and quality changes of cuttlefish stored in refrigerator temperature (at $2^{\circ} \mathrm{C}$ ) without ice treatment in terms of sensory (QIM), physicochemical ( $\mathrm{pH}$, moisture, color measurement, trimethylamine nitrogen [TMA-N], total volatile bases nitrogen [TVB-N] values and ammonia content) and microbiological (total psychrotrophic bacteria [TPBc] and mesophilic aerobic bacteria count [TMABC]) methods.

\section{MATERIALS AND METHODS}

A total of 60 whole cuttlefish (Sepia officinalis, L.) with an average weight of $440.5 \mathrm{~g}$ (range 213-668 g) were used in this study. Cuttlefish was caught by bottom gillnet from around Gokceada island close to Çanakkale in Turkey. Immediately after the catch they were placed on ice in the polystyrene box and transported to the Istanbul University, Faculty of Aquatic Sciences, Seafood Processing Technology laboratory within 24 $\mathrm{h}$ of its capture. Samples were stored in plastic pouches separately inside the polystyrene box without ice in a refrigerator set at $2 \pm 1^{\circ} \mathrm{C}$.

\section{Sensory evaluation analyses}

Sensory characteristics and overall acceptability of whole cuttlefish were assessed by a panel nine trained panellists of the Faculty of Aquatic Sciences academic staff who are MSc and $\mathrm{PhD}$ students on the basis Quality Index Method (QIM). Training consisted of 2 sessions (2h each session) until the panelists knew the quality characteristics of cuttlefish in terms of differentiating appearance, odor and texture of QIM score. Sensory characteristics and total demerit point of cuttlefish was assessed by Vaz-Pires and Seixas (2006). The sensory analyses were performed for raw cuttlefish focusing on skin: appearance, color, odor and mucus; flesh: texture, elasticity; eyes: cornea and pupil appearance; and mouth region: odour; internal bone:connection bone/head. Scores were given for all the quality attributes are summarised by the quality index method, which increases linearly with the storage time. A score between 0 to 3 demerit points or 0 to 2 demerit points were used according to sensory characteristics of whole cuttlefish and mantle.

\section{Physico-chemical analyses}

Samples were diluted with distilled water $(1: 10)$ and $\mathrm{pH}$ was measured by Thermo Scientific Model Orion Star A 214 pH/ISE meter (Beverly, MA, U.S.A).Moisture changes of samples were measured according to AOAC (1990).

Color analysis was determined using a hand-held Minolta CR-400 Chroma Meter (Minolta Camera Co.,Japan) during 10 days. The Minolta colorimeter was calibrated with a standard white plate $(D 65, Y=93.9, x=0.3155, y=0.3319)$ before each use $L^{*}, a^{*}, b^{*}$ values were measured under D65 illumination. $L^{*}, a^{*}$, $b^{*}$ values were evaluated by using triple cuttlefish were measured three times for skin and mantle, separately. Finally, the average value was calculated and recorded as result. $L^{*}$ value represents lightness from black to white between 0 and 100. While $a^{*}$ value represents from red $(+)$ to green $(-), b^{*}$ value represents from yellow $(+)$ to blue $(-)$ in color measurement of cuttlefish.

The method reported by Schormüller (1968) was used to determine total volatile base-nitrogen (TVB-N) values of samples. $10 \mathrm{~g}$ of homogenized sample was suspended in 250 $\mathrm{ml}$ pure water, made alkaline with $1-2 \mathrm{~g}$ of $\mathrm{MgO}$ and distilled. The rate of heating was adjusted so that the suspension reached boiling point in 10 minutes and distillation was performed for 20 minutes. Then, the distillate was titrated with $0.1 \mathrm{~N} \mathrm{NaOH}$. The results were expressed as mg TVB-N per 100 $\mathrm{g}$ sample. The method reported by Schormüller (1968) was used to determine trimethylamine-nitrogen (TMA-N) values of samples. Trichloroacetic acid $(90 \mathrm{ml})$, formaldehyde $(1 \mathrm{ml})$, toluene $(10 \mathrm{ml})$ and $\mathrm{KOH}(3 \mathrm{ml})$ were added to homogenizedfiltered samples and shaken, toluene phase was allowed to separate for 15 minutes, then $5 \mathrm{ml}$ from toluene phase was taken and injected into tubes. As soon as the picric acid was added into the toluene phase, samples were measured at 410 $\mathrm{nm}$ using a spectrophotometer.

Ammonia content of cuttlefish samples was determined by ammonia ion-selective electrode according to Pivarnik, Thuam, and Ellis (1998). For this, $5 \mathrm{~g}$ cuttlefish mantle samples were blended with $95 \mathrm{ml}$ of pure water and $2.0 \mathrm{ml}$ alkaline ionstrength-adjuster (ISA) solution was homogenized for 2 minutes. After Thermo Scientific Model Orion Star A 214 $\mathrm{pH} / \mathrm{ISE}$ meter was calibrated, ammonia content was measured. All results were reported as $\mathrm{mg}$ ammonia content per $100 \mathrm{~g}$ of samples. All analysis were done in three replicates.

\section{Microbiological analysis}

The samples were analyzed during storage time $(1,6,9$ and 10 days). Separate cuttlefish mantles were used for microbiological analysis. Total mesophilic aerobic bacteria count (TMABC) was carried out according to FDA (1984). Inoculation was made by pour-plate method (Merck, Kat. No: 1.05463.0500). After plates were inoculated at $35^{\circ} \mathrm{C}$ for $48 \mathrm{~h}$, plate counts were determined as colony forming units (CFU). 
Total psychrophilic bacteria count (TPBC) was carried out according to FDA (1984). Inoculation was made by pour-plate method (Merck, Kat. No: 1.05463.0500). Plates counts were determined by the colony forming units (CFU), after plates were inoculated at $7^{\circ} \mathrm{C}$ for 10 days (Baumgart, 1986; APHA, 2001).

\section{Statistical analysis}

The measurements were repeated twice with three replications. Collected data were subjected to variance analysis (ANOVA) to evaluate $\mathrm{pH}$, moisture, color, TMA-N, TVB-N and ammonia content for the stored samples. GraphPad Prism software (California Corporation, USA) was used to define significant differences between storage days by ANOVA. When a significant $(p<0.05)$ main effect was found, mean values were further analyzed using the Duncan's Multiple Range Test comparison test.

\section{RESULTS AND DISCUSSION}

During the storage at refrigerator temperature $\left(2^{\circ} \mathrm{C}\right)$ QIM changes of cuttlefish are presented in Fig. 1. The total quality changes of cuttlefish were daily determined using the total quality index score by the panelists.

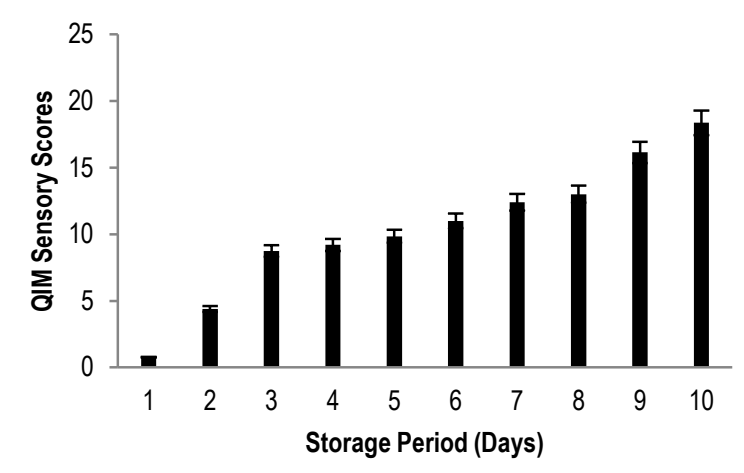

Figure 1. Sensory quality evaluation (QIM) of cuttlefish during storage period
Figure 1 indicates the changes in the quality index of cuttlefish during refrigerator set at $2^{\circ} \mathrm{C}$. From Fig. 1 it was initially identified as "excellent product" by panelists with sea fresh odor, very bright appearance and color of skin and firm texture with 0.77 total quality index score. The total quality scores (QIM) of cuttlefish increased with loss of sensorial characteristics during storage time. After $6^{\text {th }}$ days of storage, the total quality scores was reached with 11 demerit points. The panelists reported a loss of sensory quality of cuttlefish with the decrease in brightness of the skin, increase in the eye opacity and the intensification of the yellowish color of the mantle. Furthermore unacceptable odor development in the mouth region, softening in the flesh and mucus loss were also determined. According to the evaluation of the panelists the cuttlefish was not consumable with a total quality score of 16.14 after $9^{\text {th }}$ day of storage at $2^{\circ} \mathrm{C}$. Vaz-Pires et al. (2008) determined that the presence of unpleasant odor of squid and cuttlefish to be perceptible at day 6 and unacceptable at day 8 . They also reported that the sensorial rejection of cuttlefish was found at day 9 during refrigeration temperature $\left(2 \pm 2^{\circ} \mathrm{C}\right)$. Our sensorial results are in accordance with the freshness evaluation of cuttlefish stored in crushed ice reported in earlier researchers (Ganesan et al., 2005; Vaz-Pires et al., 2008).

Badiana et al. (2013) reported that QIM scheme is more accurate determination of the assessment the cuttlefish freshness quality than EU scheme. They asserted that EU scheme was not satisfactory enough in monitoring how the freshness quality evolved during storage time. The freshness quality can not be exact but only be estimated by EU scheme. The sensory characteristics of foods may vary depending on the quality of the raw material they have or the duration and temperature of storage. However human senses may not always produce precise results since they identify the color change in food subjectively. For this reason, the determination of the characteristic color changes in the food without a homogenous color using instrumental analysis method is especially important (Sengor et al., 2014). Color measurement of cuttlefish samples was summed up in Table 1.

Table 1. Physico-chemical quality parameters of cuttlefish during storage period

\begin{tabular}{|c|c|c|c|c|c|c|c|c|c|c|}
\hline \multirow{2}{*}{$\begin{array}{c}\text { Storage } \\
\text { Days }\end{array}$} & \multirow{2}{*}{$\mathrm{pH}$} & \multirow{2}{*}{$\begin{array}{c}\text { TMA-N } \\
\text { mg/100g }\end{array}$} & \multirow{2}{*}{$\begin{array}{c}\text { TVB-N } \\
\mathrm{mg} / 100 \mathrm{~g}\end{array}$} & \multirow{2}{*}{$\begin{array}{c}\mathrm{NH}_{3} \\
\mathrm{mg} / 100 \mathrm{~g}\end{array}$} & \multicolumn{2}{|c|}{$L^{*}$} & \multicolumn{2}{|c|}{$a^{*}$} & \multicolumn{2}{|c|}{$b^{*}$} \\
\hline & & & & & Mantle & Skin & Mantle & Skin & Mantle & Skin \\
\hline 1 & $6.59 \pm 0.03^{a}$ & $3.52 \pm 0.16^{a}$ & $26.25 \pm 1.32^{\mathrm{a}}$ & $7.83 \pm 0.64^{a}$ & $66.39 \pm 1.08^{a}$ & $37.30 \pm 0.90^{a}$ & $2.08 \pm 0.34^{a}$ & $1.91 \pm 0.40^{a}$ & $-2.48 \pm 2.11^{a}$ & $7.09 \pm 1.18^{a}$ \\
\hline 6 & $6.97 \pm 0.02^{b}$ & $7.87 \pm 0.25^{b}$ & $34.56 \pm 0.58^{b}$ & $35.60 \pm 0.25^{b}$ & $62.22 \pm 0.69 \mathrm{~b}$ & $38.84 \pm 1.65^{b}$ & $-1.62 \pm 0.34^{b}$ & $0.78 \pm 0.33^{b}$ & $-3.44 \pm 1.38^{b}$ & $6.34 \pm 0.99 \mathrm{~b}$ \\
\hline 9 & $7.17 \pm 0.01^{c}$ & $8.11 \pm 0.27^{c}$ & $70.76 \pm 5.45^{c}$ & $49.63 \pm 0.66^{c}$ & $60.54 \pm 2.34 c$ & $27.44 \pm 1.59^{c}$ & $-1.70 \pm 0.57^{b}$ & $0.64 \pm 0.03^{b}$ & $-2.56 \pm 3.26^{a}$ & $2.40 \pm 0.87^{c}$ \\
\hline 10 & $7.51 \pm 0.01^{d}$ & $11.33 \pm 0.21^{d}$ & $100.36 \pm 10.98^{d}$ & $56.76 \pm 0.98^{d}$ & $57.06 \pm 1.25^{d}$ & $30.39 \pm 2.70^{d}$ & $-0.89 \pm 1.23^{c}$ & $0.95 \pm 0.46^{c}$ & $3.02 \pm 5.23 c$ & $3.63 \pm 1.12^{d}$ \\
\hline
\end{tabular}

$a, b, c, d$ Different letters in the same column indicate significant differences among formulations $(p<0.05), \pm$ defines standard deviation. $(n=3)$

The color change in the mantle and skin of cuttlefish was evaluated based on the $L^{*}$ (brightness) and $b^{*}$ (yellowness) values. Accordingly, the minolta $L^{*}$ values for the mantle and skin of the cuttlefish at the beginning of this study were 66.39 and 37.30 on average, respectively. The $a^{*}$ values mantle and skin of cuttlefish changed from 2.08 to -0.89 and from 1.91 to 0.95 at the end of the storage period (on day 10 ). The $b^{*}$ values mantle and skin of cuttlefish varied from -2.48 to 3.02 and from 
7.09 to 3.63 on average respectively at the end of storage period (on day 10). In mantle and skin of cuttlefish the $L^{*}$ value representing the brightness decreased during the storage period, while mantle of cuttlefish the $b^{*}$ value increased with storage period. On the other hand skin of cuttlefish the $b^{*}$ value decreased during ten days of storage. The decrease in yellowness of the skin of cuttlefish might be due to difference in the chromatophores presented in the skin. The decrease of yellowness and brightness of the skin of cuttlefish are indicated as a sign of cuttlefish quality deterioration. Tantasuttikul et al. (2011) reported that the $L^{*}$ value showing the brightness of cuttlefish mantle slightly decreased during storage, while the $b^{*}$ value became yellowish during storage in ice. Similar results were determined with this study about increasing the $b^{*}$ value and decreasing the $L^{*}$ value of cuttlefish mantle.

$\mathrm{pH}$ measurement is an important test helpful to determine seafood freshness (Sengor et al.,2000). The initial $\mathrm{pH}$ value of the cuttlefish was 6.59 . The $\mathrm{pH}$ values were dramatically increased in accordance with chemical analyses results during storage time. The $\mathrm{pH}$ value raised to $6.97,7.17$ and 7.51 after $6^{\text {th }}, 9^{\text {th }}$ and $10^{\text {th }}$ day stored at refrigeration temperature $\left(2^{\circ} \mathrm{C}\right)$ respectively. Caglak et al. (2014) reported that the $\mathrm{pH}$ values of cuttlefish within the plastic bag (air packaged) stored at $2^{\circ} \mathrm{C}$ were found as 7.68 on the $9^{\text {th }}$ day of storage. This result is also in parallel with our findings for $\mathrm{pH}$ values of cuttlefish.

Changes in the moisture content of cuttlefish samples were measured during storage period. At the beginning of the storage period, moisture content of cuttlefish was 75.88 . It was observed that this value increased during $9^{\text {th }}$ and $10^{\text {th }}$ days except for the $6^{\text {th }}$ day. This can be explained as humidity of the environment connection with relative humidity of cuttlefish.

Total volatile base (TVB-N) in squid mantle is recommended for assessing squid quality. The chemical tests for trimethylamine (TMA) and free fatty acids (FFA) can be used as secondary quality parameters for squid quality assurance (Woyewoda \& Kee, 1980). The quality evaluation of cephalopods as per TVB-N values are classified as A quality with less than $30 \mathrm{mg} / 100 \mathrm{~g}, B$ quality $30-45 \mathrm{mg} / 100 \mathrm{~g}$ and unacceptable with more than $45 \mathrm{mg} / 100 \mathrm{~g}$, Ke et al. (1984). Generally, $\mathrm{pH}$ and TVB-N values are the main indicators for the initial decomposition of cuttlefish. In our study, the initial $\mathrm{pH}$, TVB-N, TMA-N values and ammonia content of cuttlefish were determined as $6.59,26.25 \mathrm{mg} / 100 \mathrm{~g}, 3.52 \mathrm{mg} / 100 \mathrm{~g}$ and 7.83 $\mathrm{mg} / 100 \mathrm{~g}$ respectively. After 6 days of storage the cuttlefish was still consumable with $7.87 \mathrm{mg} / 100 \mathrm{~g}$ TMA-N, $34.56 \mathrm{mg} / 100 \mathrm{~g}$ TVB-N values and $35.6 \mathrm{mg} / 100 \mathrm{~g}$ ammonia content. At the end of the $9^{\text {th }}$ day of storage the results of the chemical analysis were in parallel with the sensorial analysis and with 8.11 $\mathrm{mg} / 100 \mathrm{~g}$ TMA-N, $70.76 \mathrm{mg} / 100 \mathrm{~g}$ TVB-N values, $49.63 \mathrm{mg} / 100$ $\mathrm{g}$ ammonia content it was determined that the cuttlefish was not consumable which is above the reported critical level for TMAN and TVB-N values by Schormüller (1968). Sykes et al. (2009) reported that TVB-N exceeded the acceptable limit of 35 $\mathrm{mg} / 100 \mathrm{~g}$ muscle while TMA-N exceeded the acceptable limit of $10 \mathrm{mg} / 100 \mathrm{~g}$ muscle for cuttlefish after 9 days of ice storage.
Paarup et al. (2002) reported that TMA production increases in the cuttlefish starting from the 2nd day of storage in ice. They stated that on day 10 , concentrations of $\mathrm{NH}_{3}$ and TMA in the gutted squid constituted 61 and $59 \%$ respectively of the concentrations detected in the whole squid during stored in ice. According to our research findings cuttlefish stored as a whole without ice exceeded the limit values for TVB-N and TMA-N after 9 days of storage at $2^{\circ} \mathrm{C}$. Our measurements are in parallel with those of $\mathrm{pH}$ (initially 6.8 and reaching to 7.2 on $10^{\text {th }}$ day of storage) and TMA-N (initially $2 \mathrm{mg} / 100 \mathrm{~g}$ and reaching to $17 \mathrm{mg} / 100 \mathrm{~g} 10^{\text {th }}$ day of storage) values of whole squid stored in ice by Paarup et al. (2002). Similarly the initial pH value of the cuttlefish was 6.50 and reached to 6.91 on the $9^{\text {th }}$ day of storage at $2^{\circ} \mathrm{C}$ in ice and TVB-N exceeded the acceptable limit of $35 \mathrm{mg} / 100 \mathrm{~g}$ muscle while TMA-N exceed the acceptable limit of $10 \mathrm{mg} / 100 \mathrm{~g}$ muscle for cuttlefish after 9 days of iced storage by Sykes et al. (2009).

Changes in the microbial flora of whole cuttlefish during storage time without ice in Figure 2.

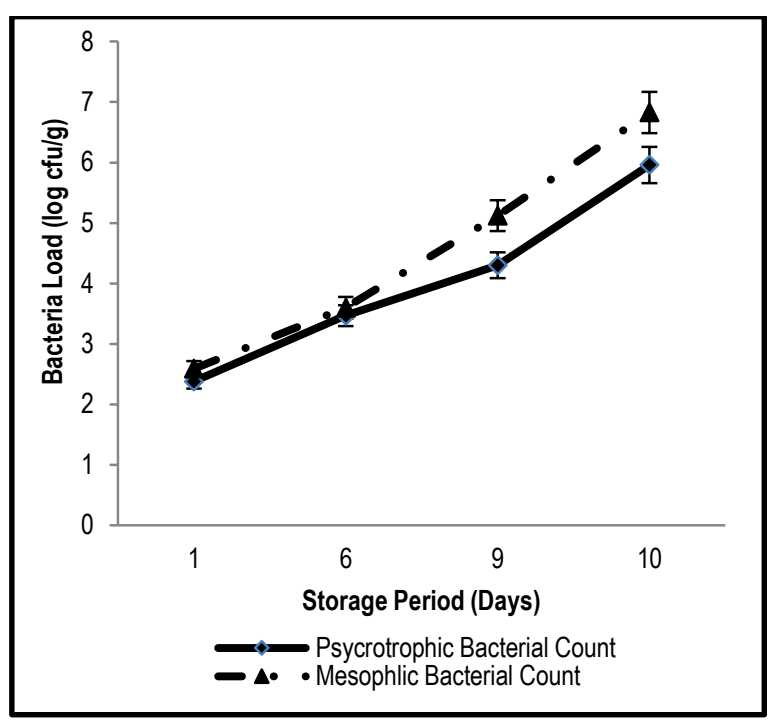

Figure 2. Microbiological quality changes of cuttlefish during storage period

The TMABC and TPBc slightly increased throughout the storage period. The initial total mesophlic aerobic bacteria count (TMABc) of the cuttlefish was $2.38 \mathrm{log} \mathrm{cfu} / \mathrm{g}$ and total psychrophilic aerobic bacteria count (TPBc) was $2.59 \mathrm{log} \mathrm{cfu} / \mathrm{g}$ in parallel with this research. After $6^{\text {th }}$ day of storage period the cuttlefish, total mesophilic aerobic bacteria count was $3.47 \mathrm{log}$ $\mathrm{cfu} / \mathrm{g}$ and total psychrophilic aerobic bacteria count was $3.6 \mathrm{log}$ $\mathrm{cfu} / \mathrm{g}$. At the end of $9^{\text {th }}$ days of storage period, total mesophlic aerobic bacteria count of the cuttlefish was a remarkable change to $5.12 \mathrm{log}$ cfu/g and total psychrophilic aerobic bacteria count was reached to $4.30 \mathrm{log}$ cfu/g. Similar results were also reached by Lapa-Guimarặes et al. (2002) with their research on contact ice and non-contact ice storage of squid. LapaGuimarặes et al. (2002) reported that at day 10 when the 
sensory quality had decreased the psychrotrophic counts were barely $1 \times 10^{5}$ and $1 \times 10^{4} \mathrm{cfu} / \mathrm{g}$ in contact ice and non-contact ice storage period.

Our findings during $9^{\text {th }}$ day of storage time neither total mesophilic aerobic bacteria nor total psychrophilic bacteria load of the cuttlefish reached the limit value of determining the spoilage.

The probable reasons for still being at a microbiologically safe condition were supposed to be storing the cuttlefish as a whole, separated and not being in contact with each other in $\mathrm{PE}$ pouches, following the hygiene rules and procedures prior to analysis and the effect of washing during cleaning the cuttlefish before the analysis. Unluturk and Turantas (1998) reported that with cleaning and washing the bacteria could be removed from the fish tissue.

\section{REFERENCES}

AOAC. (1990). Official methods of analysis of association of analitical chemists, $15^{\text {th }}$ ed., Kenneth Arlington,Virginia,USA.

APHA. (2001). Compendium for the microbiological examination of foods, $4^{\text {th }}$ ed., Washington DC.

Badiana, A., Bonaldo, A., Testi, S., Rotolo, M., Seratore, P., Giulini, G. Pagliuca, G., \& Gatta, P. P. (2013). Good handling practices of the catch The effect of early icing on the freshness quality of cuttlefish (Sepia officinalis L.). Food Control, 32, 327-333. DOI: 10.1016/j.foodcont.2012.12.019

Baumgard, J. (1986). Mikrobiologische untersuchung von Lebensmittel. Behr's Verlag. B. Behr's GmbH \& Co., Averhoffstrasse 10, 2000 Hamburg 76, 2932.

Caglak, E., Caklı, S., \& Kilınc, B. (2014). Comparison chemical, sensory, microbiological and textural changes of cuttlefish (Sepia officinalis) stored under different packaging. Bulgarian Journal of Agricultural Science, 20 , 1046-1053.

FDA. (1984). Bacteriological analytical manual $6^{\text {th }}$ ed., Food and Drug Administration, Washington DC.

Ganesan, P., Jeyasekaran, G., Maheswari, K., Shakila, R. J., \&Sukumar, D. (2005). Quality evaluation in chilled cuttlefish fillets. J. of Aquatic Food Product Technology, 14, 37-49.

Jeyasekaran, G., Shakila, R. J., \& Sukumar, D. (2012). Microbiological quality of cuttlefish (Sepia pharaonis) fillets stored in dry and wet ice. Food Science and Technology International, 18, 455-464. DOI: $10.1177 / 1082013211433069$

Ke, P. J., Burns, B. G., \& Woyewoda, A. D. (1984). Recomended procedures and guidelines for quality evaluation of atlantic short fin squid (Illex illecebrosus). Lebensmittel-Wissenchaft und-Technologie, 17, 276-281.

Lapa-Guimarặes, J., Aparecida Azvedo da Silvia, M., Eduardo de Felicio, P., \& Guzman, E. (2002). Sensory, colour and psychrotrophic bacteria analyses of squids during storage in ice. Lebensm-Wiss. U-Technol.,35, 21-29. DOI: $10.1006 /$ fstl.2001.0783

Martinsdóttir, E. (1987). Freshness measurements on cod and redfish with RT freshness grader. Reykjavik: Icelandic Fisheries Organization.

Ozogul, Y., Duysak, O., Ozoğul, F., Ozkutuk, A. S., \& Tureli, C. (2008) Seasonal effects in the nutritional quality of the body structural tissue of cephalopods. Food Chemistry, 108, 847-852 DOI: 10.1016/j.foodchem.2007.11.048

Paarup, T., Sanchez, J. A., Moral, A., Christensen, H., Bisgaard, M., \& Gram, L. (2002). Sensory, chemical and bacteriological changes during storage of iced squid (Todaropsis eblanae).Journal of Applied Microbiology, 92 , 941-950. DOI: $10.1046 /$ /.1365-2672.2002.01604.X

\section{CONCLUSION}

In this study, it was determined that the cuttlefish stored without ice at $2^{\circ} \mathrm{C}$ resumes acceptable quality aspects for 6 days of storage time in terms of sensory, microbiological and physicochemical quality indices. It was observed that sensorial and chemical quality loss and certain distortion of cuttlefish arises on the $9^{\text {th }}$ day of storage period.

\section{ACKNOWLEDGEMENTS}

Authors would like to thank Dr. Onur Gönülal for providing research materials. The authors also wish to thank the panelists who are registered MSc and PhD students at Istanbul University, The Institute of Science.

Pivarnik, L. F., Thuam, M., Ellis, P. C. (1998). Rapid determination of volatile bases in fish by using an ammonia ion-selective electrode. Journal of AOAC International, 81, 1011-22.

Schormüller, J. (1968). Tierische Lebensm. Eier. Fleisch. Buttermilsch. In Handbuch der Lebensmittel Chemie, Band III/2 Teil. Berlin-HiedelbergNew York: Springer-Verlag.

Sengor, G. F., Celik, U., Akkus, S. (2000). Determination of Freshness and Chemical Composition of Scad (Trachurus trachurus, L.). Turkish Journal of Veterinary and Animal Sciences, 24, 187-194.

Sengor, G. F. U., Balaban, M. O., Dogruyol, H., Ceylan, Z., \& Topaloglu, B. (2014). The investigation effects of antibacterial papers and timetemperature indicators (TTI) used to determine the shelf life of gilthead seabream (Sparus aurata) stored in ice. Istanbul University Scientific Research Project Unpublished Report, (YADAOP Project number:18587).Istanbul, Turkey.23 pp (in Turkish).

Sykes, A. V., Oliveira, A. R., Domingues, P. M., Cardoso, C. M., Andrade, J. P., \& Nunes, M. L. (2009). Assessment of European cuttlefish (Sepia officinalis, L.) nutritional value and freshness under ice storage using a developed Quality Index Method (QIM) and biochemical methods. Lebensm.-Wiss. Technol., 42, 424-432. DOI: 10.1016/j.lwt.2008.05.010

Tantasuttikul, A., Kijroongrojana, K., Benjakul, S. (2011). Quality indices of squid (Photololigo duvaucelii) and Cuttlefish (Sepia aculeata) stored in Ice. Journal of Aquatic Food Product Technology,20, 129-147. DOI: 10.1080/10498850.2010.548114

TUIK. (2016). Fishery Statistics.Retrieved from http://www.tuik.gov.tr

Unal, G. F. (1991). Research of quality changes in frozen cuttlefish (Sepia officinalis, L., 1758) (MSc Thesis).Ege University, Institute of Science,71 sayfa, İzmir, Turkey.

Unluturk, A. \& Turantas, F. (1998). Food Microbiology. In A.Unluturk \& F.Turantas (Eds.), Microorganism Food Relations. (pp. 3-9).Izmir, Turkey, Mengi Tan Basımevi, 605 pp.

Vaz-Pires, P. \& Seixas, P. (2006). Development of new quality index method (QIM) schemes for cuttlefish and broadtail shortfin squid. Food Control, 17, 942-949. DOI: 10.1016/j.foodcont.2005.07.004

Vaz-Pires, P., Seixas, P., Mota, M., Lapa-Guimarặes, J., Pickova ,J., Lindo, A. \& Silva, T. (2008). Sensory, microbiological, physical and chemical properties of cuttlefish (Sepia officinalis) and broadtail shortfin squid (IIlex coindetii) stored in ice. Food Sci. and Technology, 41, 1655-1664. DOI: 10.1016/j.Iwt.2007.10.003

Woyewoda, A. D. \& Ke, P. J. (1980). Laboratory quality assessment of canadian atlantic squid (Illex illecebrosus). Report No.902,26 pp.,Nova Scotia,Canada. 